\title{
Feedbacks Between the Nitrogen, Carbon and Oxygen CyCles
}

\author{
Ilana Berman-Frank, Yi-bu Chen, Yuan Gao, Katja Fennel, Mick Follows, \\ Allen J. Milligan, and Paul Falkowski
}

\section{Contents}

1. Evolutionary History of the N, C, and O Cycles 1512

1.1. Nitrogen in the preoxygenated world/oceans 1512

1.2. Oxygenation of the early atmosphere: The influence of shelf area and nitrogen fixation rates

2. Nitrogen-Fixation, Nitrogenase, and Oxygen. Evolutionary Constraints,

Adaptations of Cellular Pathways and Organisms, Feedbacks to Global

$\mathrm{N}, \mathrm{C}, \mathrm{O}$ Cycles

2.1. Evolutionary constraints for nitrogen fixation and adaptive strategies $\quad 1515$

2.2. Adaptive strategies. Oxygen consumption-The Mehler reaction 1520

2.3. Biological feedbacks to the global N, C, and O cycles 1523

3. Sensitivity of the Nitrogen, Carbon, and Oxygen Cycles to Climate Change 1524

3.1. Aeolian iron and stratification of the surface mixed layer in the future $\quad 1525$

3.2. Interactions of the oxygen and nitrogen cycles: Nitrification and denitrification

3.3. Ocean circulation and the global ocean cycles of nitrogen, oxygen and carbon

3.4. Implications for the global carbon cycle $\quad 1529$ 4. Summary and Conclusions 1530 References

\begin{abstract}
The global cycles of nitrogen, carbon, and oxygen are inextricably interconnected via biologically mediated, coupled redox reactions. The primary reactions include nitrogen fixation, nitrification, denitrification, oxygenic photosynthesis, and respiration. The ensemble of these reactions produces a connected set of cycles that allows the major pool of each element to exist far from its thermodynamic equilibrium state. The evolutionary history of these cycles has been imprinted in the structure and in the performance of genes and proteins. While the selection of continuously modified genes, a core set of the genes responsible for the underlying processes remained remarkably conserved. Here we review the evolutionary history of the nitrogen, carbon, and oxygen cycles, and
\end{abstract}


focus on the constraints on aquatic nitrogen-fixing cyanobacteria to illustrate the complex interplay and feedback mechanisms from the cellular and organism levels to the global biogeochemical cycles. Finally, we consider the sensitivity of these feedbacks to forecasted scenarios of climate change.

\section{Evolutionary History of the N, C, ANd O CyCles}

\section{s0030 1.1. Nitrogen in the preoxygenated world/oceans}

p0100 All organisms on Earth are composed primarily of the six light elements: H, C, N, O, S, and P. Hydrogen was created 13.7 Ga (billion years ago) in the "Big Bang", while the other five elements were created via fusion reactions in stars. Their relative abundance scales, to a first order, with the inverse of their atomic mass. Hence, among these five elements in our solar system, $\mathrm{H}$ is the most abundant and $\mathrm{P}$ is the rarest (Williams and Frausto Da Silva, 1996). When our solar system was formed, ca. $4.56 \mathrm{Ga}$, a complement of elements was imported from supernovae and distributed among the planets and planetary bodies (e.g., moons and asteroids) and our sun. During planetary accretion, formation of dense phases caused siderophile elements (e.g. Fe metal) to move towards the core, while lighter elements tended to migrate toward the mantle or the atmosphere.

p0110 In early models of planetary accretion, the process was thought to be relatively slow, such that elements such as $\mathrm{N}$ and $\mathrm{C}$ had high probabilities of combining with $\mathrm{H}$ to form highly reduced molecules such as $\mathrm{NH}_{3}$ and $\mathrm{CH}_{4}$ (Urey, 1952). However, based on more detailed observations of how planets are formed, as well as on theoretical calculations about the rate of outgassing of $\mathrm{H}_{2}$ to space, a much larger fraction of $\mathrm{C}$ and $\mathrm{N}$ probably existed in higher oxidized states such as $\mathrm{CO}_{2}$ and $\mathrm{N}_{2}$ (Holland, 1984), but almost certainly not $\mathrm{NO}_{x}$. Chemically, $\mathrm{N}_{2}$ is highly inert. The biologically accessible form of the element requires that it be used in dissimilatory metabolism (such as bacterial conversion from nitrate to nitrite) or react either at a lower reducing level, with $\mathrm{H}$, to form $\mathrm{NH}_{3}$, or at a higher oxidized level, $\mathrm{NO}_{x}$, from which it can be biologically reduced to $\mathrm{NH}_{3}$. Assuming the described initial conditions, the environment of the Archean oceans exerted a strong selection pressure for processes that could reduce $\mathrm{N}_{2}$ to $\mathrm{NH}_{3}$, thereby making $\mathrm{N}_{2}$ a sink for electrons in an electron market where oxidized species are relatively rare. Under such conditions, biological reduction of $\mathrm{N}_{2}$ could serve as a pathway for the oxidation of organic carbon under anaerobic conditions, or as a detoxyase for detoxification of cyanides, which could have been common in the ancient oceans (Fani et al., 2000; Postgate, 1998). This redox couple, namely the oxidation of organic carbon and the reduction of $\mathrm{N}_{2}$, is sensitive to oxygen, and hence the biologically-mediated geochemical cycles of the three elements, $\mathrm{C}, \mathrm{N}$, and $\mathrm{O}$, are inextricably interconnected (Box 35.1).

p0120 In this chapter we examine the connections between these three elements and focus on biological nitrogen-fixation to illustrate the regulatory control of biological processes on the geochemistry of the oceans and Earth over the past 4 billion years. 
b0010 Box 35.1 Links Between Oceanic Nitrogen and Oxygen Cycles

p0010

p0020

p0030

p0040

p0050

Au8

p0060

(1)

Hence, the sources and sinks of dissolved inorganic nitrogen and dissolved oxygen in the ocean are intimately linked and their global cycles coupled.

The oceanic cycles of nitrogen and oxygen are intimately linked through the processes of nitrification and denitrification. These processes constitute the key source and sink of fixed nitrogen in the ocean and control its global budget. The coupling of the nitrogen and oxygen cycles has implications for the long-term chemical evolution of the ocean and the atmosphere, variations in the oceans' nitrogen budget, and the nitrogen limitation of marine ecosystems over centennial to very long timescales.

During photosynthesis nutrients, including nitrogen, are assimilated into organic matter and molecular oxygen is produced, depicted schematically by

$$
106 \mathrm{CO}_{2}+16 \mathrm{NO}_{3}+\mathrm{H}_{2} \mathrm{PO}_{4}+122 \mathrm{H}_{2} \mathrm{O} \leftrightarrow \mathrm{C}_{106} \mathrm{H}_{263} \mathrm{O}_{110} \mathrm{~N}_{16} \mathrm{P}+138 \mathrm{O}_{2}
$$

Here we assume a source of fixed nitrogen in the form of nitrate. Alternatively, diazotrophs can fix their own nitrogen, reducing $\mathrm{N}_{2}$ gas to the level of ammonium in order to be assimilated for protein synthesis. Ammonium may be oxidized by nitrifying bacteria to produce nitrite and nitrate and consuming molecular oxygen:

$$
\mathrm{NH}_{4}+2 \mathrm{O}_{2} \leftrightarrow \mathrm{NO}_{2}+2 \mathrm{H}_{2} \mathrm{O}
$$

The sequence of nitrogen fixation and nitrification is a source of fixed nitrogen and a sink of dissolved oxygen in the ocean. Aerobic respiration of organic material by heterotrophic bacteria also consumes oxygen and releases nitrogen to the dissolved inorganic pool; the reverse of (35.1).

Under very low oxygen conditions, denitrification, resulting from the anaerobic reduction of nitrate by heterotrophic bacteria, consumes fixed nitrogen in the form of nitrate, ultimately regenerating $N_{2}$ gas (Froelich et al., 1979).

$$
\mathrm{C}_{106} \mathrm{H}_{263} \mathrm{O}_{110} \mathrm{~N}_{16} \mathrm{P}+84.8 \mathrm{HNO}_{3} \rightarrow 106 \mathrm{CO}_{2}+42.4 \mathrm{~N}_{2}+16 \mathrm{NH}_{3}+\mathrm{H}_{3} \mathrm{PO}_{4}+148.4 \mathrm{H}_{2} \mathrm{O}
$$

\subsection{Oxygenation of the early atmosphere: The influence of shelf area and nitrogen fixation rates}

p0130 Geochemical evidence suggests that there were delays of several hundred million years between the rise of oxygenic photosynthesis, the oxygenation of the atmosphere, and the oxygenation of the deep ocean. Photosynthesis (evidenced by cyanobacterial microfossils and biomarkers) rose as early as $3.5 \mathrm{Ga}$ (billion years before present; (Schopf, 1993)) and had been solidly established by 2.7-2.5 Ga (Brocks et al., 1999; Knoll, 1996; Schopf, 1993; Summons et al., 1999). Data from red beds, detrital mineral deposits, and sulfur isotopes indicate the rise of atmospheric oxygen around 2.4 Ga (Bekker et al., 2004; Chandler, 1980; Des Marais et al., 1992; Farquhar et al., 2000; Holland and Rye, 1997; Knoll, 1996; Summons et al., 1999). The deep ocean appears to have remained anoxic at least until the disappearance of 
banded iron formations at $1.8 \mathrm{Ga}$ (Holland, 1984), and possibly as late as $0.8 \mathrm{Ga}$ (Arnold et al., 2004; Canfield, 1998; Canfield and Teske, 1996).

The hypothesis that oxygen feedbacks on $\mathrm{N}$ and $\mathrm{C}$ cycles substantially delays the rise of atmospheric oxygen is supported by box model calculations, incorporating ocean circulation and ocean-atmosphere gas-exchange with the geochemical cycles of $\mathrm{C}, \mathrm{N}$, and $\mathrm{O}$ (Fennel et al., 2005; Fig. 35.1). The model has four ocean boxes (high and low latitude surface, deep ocean and shelf seas) coupled to a single atmospheric reservoir and represents the nitrogen and oxygen cycle interactions excluding the sedimentary processes (Fig. 35.1). Application of this model shows that, when initialized with

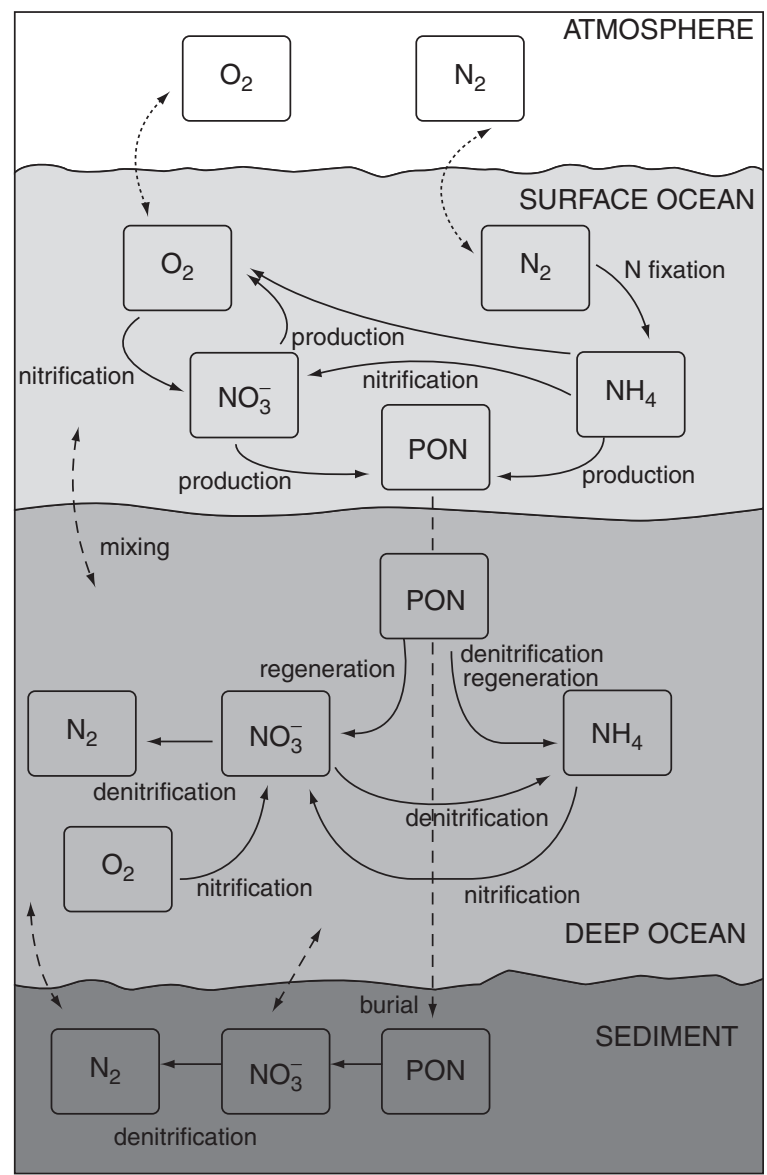

f0010 Figure 35.1 Schematic depiction of the coupled, global ocean nitrogen and oxygen cycles. Dissolved inorganic nitrogen and nitrogen fixation fuel oxygenic photosynthesis in the surface ocean, helping to sustain atmospheric and deep ocean oxygen levels. In the deep ocean, oxygen is typically consumed during the microbial respiration of organic matter, producing dissolved inorganic nitrogen. However, in low oxygen waters and sediments, denitrification fuels the oxidation of organic matter, ultimately removing dissolved inorganic nitrogen from the water column. In the early ocean, initial oxygenation of the water column may have inhibited the build up of nitrate which would have been quickly consumed as the oxidant of organic matter. 
anaerobic conditions, ammonium is originally stable in the reduced deep ocean. Yet, as free oxygen becomes available in the ocean, ammonium is converted to nitrate, which can be rapidly reduced to $\mathrm{N}_{2}$, thus decreasing the pool of fixed inorganic nitrogen. Hence, the interaction between $\mathrm{N}, \mathrm{C}$, and $\mathrm{O}$ during a transition from an anaerobic to aerobic ocean leads to a strong negative feedback. During this low-nitrogen stage, which can last several 100 million years in our simulations, export production is severely attenuated. Unless some exported carbon is buried, oxygen cannot accumulate in the upper ocean or atmosphere.

p0150 The net rate of oxygen production during the low (fixed)-nitrogen stage at the anoxic/oxic transition depends on several factors, including the burial of organic matter and the rate of oxygen consumption during nitrification. In our model studies, the oxygenation of the ocean and atmosphere critically depended on the presence of shallow continental shelf seas (Fennel et al., 2005). The burial of organic matter is much more efficient in shallow continental shelves than in the deep ocean (Hartnett et al., 1998) hence, rates of organic matter burial and net oxygen production should increase as a function of the relative area of continental shelves and shallow seas (Berner, 1984). The relationship between the area of continental shelves, carbon burial, and oxygen production highlights the fundamental role of tectonic processes, especially seafloor spreading, in controlling eustatic sea level and the area of shallow seas (Miller et al., 2005), and in determining the rate of oxygen evolution. The model also demonstrates that an increase in the oceanic phosphate inventory will enhance the net rate of oxygen production owing to higher export. In a fully oxidized ocean, it also potentially leads to an increased inventory of fixed inorganic nitrogen. Furthermore, the rate of net oxygen production is very sensitive to the $\mathrm{N}_{2}$ fixation rate, which suggests that the initial increase of oxygen had an additional negative feedback on oxygen production by compromising nitrogenase activity both directly and through trace metal limitation (Anbar and Knoll, 2002; Falkowski, 1997) (see below and Fig. 35.2)

p0160 An extended period of severe nitrogen limitation and low productivity during the Proterozoic is consistent with the $\delta^{13} \mathrm{C}$ record of carbonates, which indicates large variations at the beginning and end of the Proterozoic, but not in the intervening period (Des Marais et al., 1992). Our model studies suggest that during the enhanced tectonic activity at the end of the Proterozoic, changes in the global shelf area or in the oceanic phosphate inventory could have triggered the oxygenation of the deep ocean.

\section{Nitrogen-Fixation, Nitrogenase, and OXygen. EVOLUTIONARY CONSTRAINTS, AdAPTATIONS OF CELLULAR Pathways and Organisms, Feedbacks to Global N, C, O CYCLES}

\subsection{Evolutionary constraints for nitrogen fixation and adaptive strategies}

p0170 Over a 200 million year period, centered around 2.32 billion years ago (Bekker et al., 2004), the partial pressure of oxygen $\left(\mathrm{pO}_{2}\right)$ rose from $<4 \times 10^{-6}$ atm to $>0.03 \mathrm{~atm}$ (Pavlov and Kasting, 2002; Rye and Holland, 1998). This emerging environment 


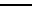
$\%$ Oxygen in air
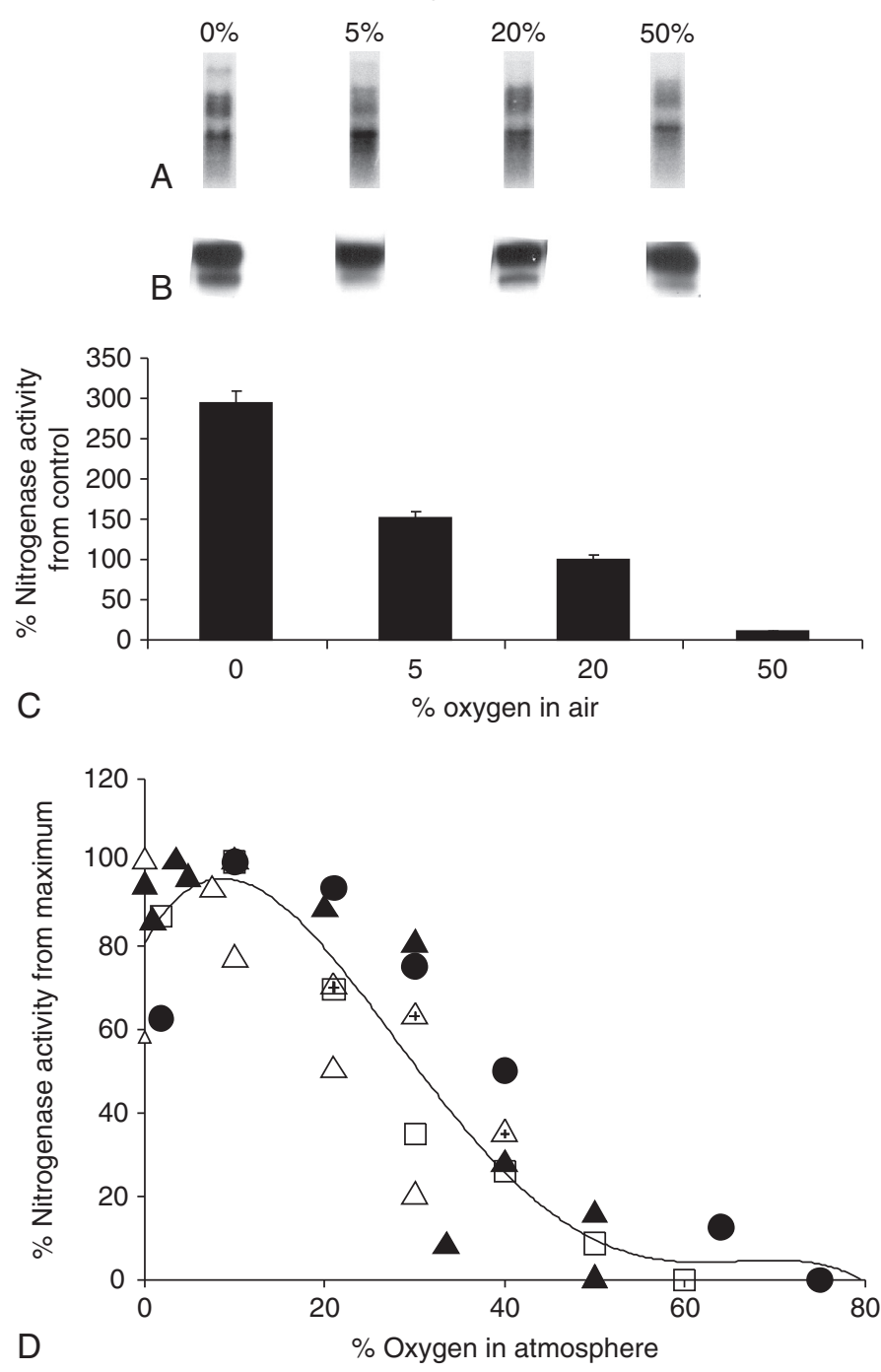

f0020 Figure 35.2 (A) nif HDK transcript abundance for Trichodesmium IMS101 cultures bubbled with nitrogen $\left(0 \%\right.$ oxygen), $5 \%, 20 \%$, and $50 \% \mathrm{O}_{2}$ for $5 \mathrm{~h}$. (B) Western blots of nitrogenase protein abundance (challenged with universal $\mathrm{Fe}$-protein polyclonal antibodies) for the above experiment (C) Nitrogenase activity (presented as \% of air-control) measured by acetylene reduction for the above experiment $1 \mathrm{~h}$ after induction of bubbling. (D) Relationship between $\mathrm{O}_{2}$ concentrations and nitrogen fixation (\% from maximum rates) forTrichodesmium IMS101 and other diazotrophs. Filled triangles: experimental data from our cultures of Trichodesmium IMS101; empty triangles with cross-Trichodesmium NIBB1067 (Ohki and Fujita, 1988), empty trianglesTrichodesmium spp. field populations (Mague et al., 1977; Saino and Hattori, 1982), black circlesAnabaena cylindrical (Gallon et al., 1993), black squares-Gloeothece (Nageli) (Gallon et al., 1993). Short-term (1-2 h) anaerobic incubation yields maximum nitrogenase activity for aerobic diazotrophs (Fig. 2C). On longer time scales, respiratory requirements will yield maximum activity (in vivo) at microaerobic oxygen concentrations (Fig. 2D). 
especially challenged diazotrophic cyanobacteria, the only diazotrophs capable of oxygenic photosynthesis, yet having to contend with the innate sensitivity of the nitrogenase enzyme to molecular oxygen. Diazotrophic cyanobacteria provide an elegant case-study of how the interplay between the N, C and $\mathrm{O}$ cycles influenced the adaptation of key metabolic processes, and how these cellular processes feed back into the aquatic and global systems. In this section we focus on the evolutionary constraints on nitrogen-fixation in cyanobacteria. We then discuss how these biological controls feed back into the geochemical cycles.

p0180 The evolutionary roots of nitrogen fixation, inferred from molecular phylogenetic analyses of nifH genes, suggest that the genes encoding for nitrogenases are ancient and underwent horizontal gene transfer, gene duplication, recruitment and fusion (Raymond et al., 2004). Indeed, phylogenic analyses do not rule out the possibility that nitrogenase was present in the last universal common ancestor (LUCA) and, therefore predates the divergence of the archaea and bacteria (Fani et al., 2000; Raymond et al., 2004; Woese, 1998), or if it evolved in methanogenic archaea and was subsequently transferred to a primitive bacterium (Raymond et al., 2004). In either scenario, the catalytic subunits of the enzyme complex clearly indicate that the original enzyme existed long before the oxygenation of Earth's atmosphere (Broda and Pesheck, 1983) and that trace elements such as Fe, Mo, and $\mathrm{V}$ additionally modulated its evolutionary trajectory.

p0190 The influence of required trace elements on the evolution of nitrogenase has been discussed by several authors (Anbar and Knoll, 2002; Kustka et al., 2003; Raven, 1988; Raymond et al., 2004). The availability of iron influences $\mathrm{N}_{2}$ fixation in cyanobacteria, from its direct effect on Fe-rich protein synthesis such as nitrogenase, to effects on photosynthesis, growth, and global productivity (Berman-Frank et al., 2001; Falkowski, 1997; Kustka et al., 2003; Mills et al., 2004; Paerl et al., 1994). In the anaerobic environments of the Archean oceans, Fe would have been found predominantly in its reduced form (FeII) rather than FeIII (Anbar and Knoll, 2002 and Table 1 in Berman-Frank et al., 2003). The necessity for nitrogen selected for nitrogenase, while the availability of reduced iron selected for the metal complement of nitrogenase. Both laboratory studies (Berman-Frank et al., 2001) and field simulations (Mills et al., 2004) show a direct link between the availability of Fe and nitrogen fixation rates in environmentally important diazotrophs (see also Section IIIa). Thus, diazotrophy and subsequent primary production are predicted to be limited in the iron deficient regions of the subtropical and tropical oceans, such as the contemporary South Pacific.

p0200 Molybdenum (Mo) is another essential metal co-factor of nitrogenase. Mo, a rare trace element is much more abundant in the contemporary ocean than under the anaerobic conditions prevailing when nitrogenase first evolved, and is also required in the bacterial reduction of nitrate to nitrite (Williams and Frausto Da Silva, 2002). In the anoxic, asulfidic Archean oceans, up to $90 \%$ of the Mo would have been complexed in relatively insoluble sulfide minerals in igneous rocks (Anbar and Knoll, 2002; Falkowski, 2001; Williams and Frausto Da Silva, 1996). Limited availability of Mo may have been exacerbated in the mid-Proterozoic, where weathering, under a moderately oxidizing atmosphere, would have enhanced the delivery of sulfate $\left(\mathrm{SO}_{4}{ }^{2-}\right)$ and molybdate to the deep ocean. Combined with 
primary production in the surface waters, this would have resulted in extremely high $\mathrm{H}_{2} \mathrm{~S}$ concentrations and removal of Mo via increased precipitation and formation of active thiomolybdate $\left(\mathrm{MoS}_{4}{ }^{2-}\right)$ (Anbar and Knoll, 2002; Arnold et al., 2004). Whereas alternative, older nitrogenases exist, in which Fe or $\mathrm{V}$ were replaced by Mo, these forms are catalytically less efficient. Interestingly, Mo-independent nitrogenases have been found only in heterocystous diazotrophs (phylogenetically the most recently diverging group - see discussion below) but not in non-heterocystous species (Bergman et al., 1997).

Past depletions in dissolved inorganic phosphate may have also limited nitrogenfixation and primary production due to high adsorption of phosphate by iron-rich minerals. Indeed, based on adsorption isotherms in banded iron formations, sea-water phosphate concentrations in the Archean have been suggested to have been more than ten fold lower than the present values $(0.15-0.6 \mu \mathrm{M}$ versus the modern value of $2.3 \mu \mathrm{M})$ (Bjerrum and Canfield, 2002). Thus, present restrictions of phosphate on $\mathrm{N}_{2}$ fixers in some oligotrophic areas such as the western subtropical Atlantic may have correlations in the paleoceanographic records of the late Archean eon.

p0230 Nitrogen fixation is metabolically costly, requiring relatively large inputs of energy, reducing power, ancillary antioxidant enzymes and metal co-factors such as iron and Mo (Raven, 1988; Kustka, 2003 \#2737). A priori, the nitrogenase enzyme is notorious for its sensitivity to molecular oxygen and for the irreversible damage to the the $\mathrm{Fe}_{4} \mathrm{~S}_{4}$ clusters, in-vitro (Burgess and Lowe, 1996). Moreover, high oxygen stress causes proteolysis of nitrogenase subunits (Durner et al., 1996), suppresses nitrogenase synthesis, and leads to a shortage of respiratory substrates and reductants necessary for nitrogen fixation and assimilation (Gallon, 1992). Inhibitory effects of moderate oxygen levels, or short exposure times, in-vivo may be reversed, leading to an increase in nitrogen fixation rates (Gallon, 1992; Ludden and Roberts, 1995; Pan and Vessey, 2001; Prosperi, 1994; Yakunin et al., 2001) and, in some diazotrophs, to post-translational modification of the Fe protein from an inactive to active form (Ernst et al., 1990; Jounneau et al., 1983; Ohki et al., 1991; Sweet and Burris, 1982; Zehr et al., 1993).

p0240 The fundamental constraint of the two conflicting processes has led to several adaptations including spatial (e.g. heterocystous cyanobacteria) and temporal separation of photosynthesis and $\mathrm{N}_{2}$ fixation (e.g. unicellular species such as Cyanothece), or a combination of both (e.g. in the non-heterocystous colonial forms such as Trichodesmium). The oxygen protection mechanisms have been the focus of several reviews examining molecular, phylogenetic, physiological, morphological, regulatory, and evolutionary adaptations in cyanobacteria (Adams, 2000; Bergman et al., 1997; Berman-Frank et al., 2003; Bohme, 1998; Fay, 1992; Gallon, 1992, 2001; Tuli et al., 1996). The various strategies to overcome the inherent conflict between oxygenic photosynthesis and nitrogen fixation reflect the wide-ranging flexibility and niches occupied by cyanobacteria: from anaerobic sediments to pelagic waters saturated with oxygen. Molecular phylogenies, of $\mathrm{N}_{2}$ fixers using the nif $\mathrm{H}$ gene and small subunit ribosomal RNA sequences, showed no correlation between the phylogenetic relationships and the type of $\mathrm{N}_{2}$ fixation (Raymond et al., 2004; Turner et al., 2001). This lack of correlation suggests multiple gains and/or losses of $\mathrm{N}_{2}$ fixation among the different cyanobacteria (Raymond et al., 2004; Turner 
et al., 2001). The loss of cyanobacterial nif genes implies that different strategies arose early in the evolution of the clade, where some organisms were able to adapt to an oxic world, while others were not (e.g. Oscillatoria). Commonly, many phylogenies show the most recent phylogenetic branching (both for nifH and RNA trees) in filamentous species where complete segregation of $\mathrm{N}_{2}$ fixation and photosynthesis was achieved with the evolution of heterocystous cyanobacteria (Wolk et al., 1994).

Heterocystous cyanobacteria are predominantly terrestrial, fresh water and coastal species, inhabiting eutrophic or brackish environments (e.g. the Baltic Sea), with a few epiphytic and symbiotic representatives in the marine environment (Paerl and Zehr, 2000). Very few heterocystous free-living species are found in the pelagic oceans, though recently a novel species was found, designated Anabaena gerdii (Carpenter and Janson, 2001). The heterocyst glycolipid envelope may confer an advantage for cyanobacteria inhabiting temperate brackish and fresh waters. These waters are characterized by an increase in $\mathrm{O}_{2}$ flux by $\sim 25 \%$ from that in sea water, and thus the thick glycolipid layer can help decrease diffusion of oxygen into the heterocysts (Staal et al., 2003a). At higher temperatures, typical of tropical waters, the glycolipid envelope of the heterocyst does not provide additional protection against oxygen, which may explain the paucity of heterocystous free-living bacteria in such environments (Staal et al., 2003a).

p0260 In addition to specialized niche selection and avoidance strategies, whereby nitrogen fixation is spatially or temporally separated from photosynthesis, oxygen concentrations influence transcription, translation, and changes in nitrogenase activity of cyanobacteria. We demonstrate this with results from the bloom-forming cyanobacterium Trichodesmium IMS101, which contributes significantly to nitrogen fixation in the tropical and sub-tropical oceans. Sequence and structural analyses of its nitrogenase are similar to those of other diazotrophic organisms (Zehr et al., 1997), and there is a post-translational modification between the active and nonactive form of the protein under natural and induced conditions (Ben-Porath et al., 1993; Ohki et al., 1991). The abundance of nifH transcripts and its corresponding gene product were assayed in Trichodesmium cultures incubated for $5 \mathrm{~h}$ with $0,5,21$ (present atmospheric level-PAL), and 50\% $\mathrm{O}_{2}$ (Fig. 35.2A). The results indicate that extracellular $\mathrm{O}_{2}$ does not significantly influence transcription or translation of nifH on this time scale (Fig. 35.2A and B). In contrast, nitrogenase activity was strongly depressed by $\mathrm{O}_{2}$; at $50 \% \mathrm{O}_{2}>90 \%$ of the nitrogenase activity was inhibited within $1 \mathrm{~h}$ (Fig. 35.2C).

Post-translational modification of activity appears relatively common in diazotrophic cyanobacteria and operates at much lower concentrations of oxygen then those required for repression of nif genes (Dominic et al., 1998; Tuli et al., 1996). A compilation of published data on the response of nitrogen fixation to varying ambient $\mathrm{O}_{2}$ concentrations suggests a general relationship that is consistent with both the short-term response of the enzyme to $\mathrm{O}_{2}$ and the organisms' longer evolutionary adaptations where $\mathrm{O}_{2}$ is used as sink for electrons in respiration (Fig. 35.2D). On average, 20-30\% of the enzymatic activity is inhibited at present atmospheric oxygen concentrations of $21 \%$ (Fig. 35.2D).

In Trichodesmium spp., maximum nitrogen fixation occurs at oxygen concentrations of $2.5-5 \%$ PAL. Under truly anaerobic conditions, the Embden-Myerhof 
(glycolysis) pathway apparently cannot supply sufficient substrates through fermentative reactions to meet the demands of nitrogen fixation. Hence, in vivo, the activity of the enzyme declines. As oxygen concentrations increase above 5\%, the enzyme activity is inhibited, with only $\sim 70-80 \%$ activity measured at atmospheric oxygen concentrations of $21 \%$. At oxygen concentrations greater than $30 \%$, a sharp drop in activity reduces fixation efficiency (potential) to $<10 \%$ within minutes. This pattern of an inefficient nitrogenase is corroborated in data from other aerobic cyanobacteria such as in the heterocystous Anabaena and in the unicellular Gloethece (Fig. 35.2D). In these cyanobacteria, lowering the oxygen below atmospheric concentrations also enhances relative nitrogenase activity at short durations. However, at very low oxygen concentrations, lack of respiratory production of energy and substrates ultimately affects nitrogen fixation. Thus, in Trichodesmium for example, low oxygen stress caused faster mortality and biomass crashes after $\sim 48 \mathrm{~h}$ (Berman-Frank, unpublished).

s0070

p0290 tion) and the photosynthetic reduction of $\mathrm{O}_{2}$, termed pseudocyclic photophosphorylation or the Mehler reaction (Box 35.2). In contrast to terrestrial C3 plants, which have relatively high rates of photorespiration, photorespiration of oceanic phytoplankton is usually low when dissolved inorganic carbon concentrations in seawater are at equilibrium $(\sim 2 \mathrm{mM})$ with the atmosphere. Moreover, cyanobacteria operate a $\mathrm{CO}_{2}$ concentrating mechanism (CCM) which raises the $\mathrm{CO}_{2}$ concentration in the vicinity of RubisCO and inhibits oxygenase activity (Kaplan and Reinhold, 1999).

p0300 The Mehler reaction is a photochemical reduction of $\mathrm{O}_{2}$ to $\mathrm{H}_{2} \mathrm{O}_{2}$ or $\mathrm{H}_{2} \mathrm{O}$ in photosystem I (Box 35.2). Mehler activity is thought to be a mechanism for energy dissipation under high light intensities or when carbon fixation is limited by supply

Box 35.2 The Mehler reaction (pseudocyclic photophosphorylation)

In 1951, the late Alan Mehler (1951) observed that chloroplasts can use oxygen as an electron acceptor. The reaction sequence is

$$
\begin{gathered}
\mathrm{H}_{2} \mathrm{O}+2 \mathrm{O}_{2} \rightarrow 2 \mathrm{O}_{2}+2 \mathrm{H}^{+}+\frac{1}{2} \mathrm{O}_{2}, \\
2 \mathrm{O}_{2}+2 \mathrm{H}^{+} \rightarrow \mathrm{H}_{2} \mathrm{O}_{2}+\mathrm{O}_{2}
\end{gathered}
$$

and, in the presence of catalase:

$$
\mathrm{H}_{2} \mathrm{O}_{2} \rightarrow \mathrm{H}_{2} \mathrm{O}+\frac{1}{2} \mathrm{O}_{2} .
$$

Net gas exchange is absent since the overall electron transport reaction which involves both Photosystems II and I is:

$$
\mathrm{H}_{2} \mathrm{O}+2 \mathrm{O}_{2} \rightarrow \mathrm{H}_{2} \mathrm{O}+2 \mathrm{O}_{2}
$$


of inorganic carbon (Helman et al., 2003). Since the products of $\mathrm{O}_{2}$ reduction are often superoxide and hydrogen peroxide (with superoxide dismutase catalyzing the reduction of superoxide to peroxide), Mehler activity has been hypothesized to be a metabolic defect rather than an adaptive strategy (Patterson and Myers, 1973). However, in the cyanobacterium Synechocystis sp. (PCC 6803), superoxide is reduced directly to water without a hydrogen peroxide intermediate (Helman et al., 2003). This single step reduction of superoxide to water is catalyzed by A-type flavoproteins; two of which (flv1, flv3) were identified as essential for this activity (Helman et al., 2003). Examination of the genome of Trichodesmium, identifies homologous genes to flv1 and flv3 with $62 \%$ and $67 \%$ sequence identity, respectively (Milligan et al., In Press).

Mehler activity is generally considered a process which can only consume photosynthetically derived $\mathrm{O}_{2}$, and it cannot cause net consumption of $\mathrm{O}_{2}$ because PSI activity relies on photosynthetically derived electrons (Kana, 1993). Yet, the shared-arrangement of photosynthetic and respiratory electron transport chains in cyanobacteria allows electrons from respiratory derived $\mathrm{NAD}(\mathrm{P}) \mathrm{H}$ to feed into the plastoquinone pool of the photosynthetic electron transport chain and reduce PSI (Schmetterer, 1994). Through the translocation of reductant (i.e. glucose 6-phosphate) from cells with functional PSII, Mehler activity can result in a net consumption of $\mathrm{O}_{2}$ in cells (or heterocysts) which have no PSII activity and in which nitrogen is fixed (Fig. 35.3).

p0320 Results from Trichodesmium provide an example of the Mehler pathway's role in modulating oxygen and facilitating nitrogen-fixation. In this species, under nitrogen-fixation condition, approximately $50 \%$ of gross $\mathrm{O}_{2}$ production is consumed through Mehler activity (Fig. 35.4); this is about twice the rate reported for Synechococcus ( $25 \%$ of gross $\mathrm{O}_{2}$ production) exposed to photoinhibitory irradiances (Kana, 1992). Mehler activity is dependent both on the time of day and the nitrogen source (Fig. 35.4). The period of maximum $\mathrm{N}_{2}$ fixation is coincident with a decline in the net production of $\mathrm{O}_{2}$ and a rise in the consumption of oxygen via Mehler activity, which is consistent with the hypothesized role of this pathway as a mechanism to protect nitrogenase from $\mathrm{O}_{2}$ damage. In nitrate-grown Trichodesmium

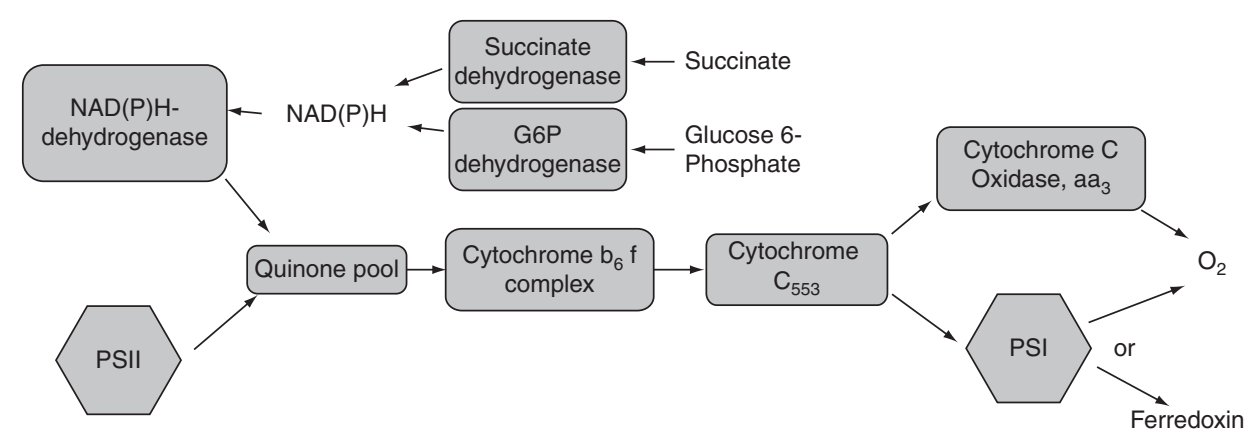

f0030 Figure 35.3 Photosynthetic and respiratory electron transport chains in cyanobacteria showing the shared electron carriers of each pathway (Schmetterer,1994). 

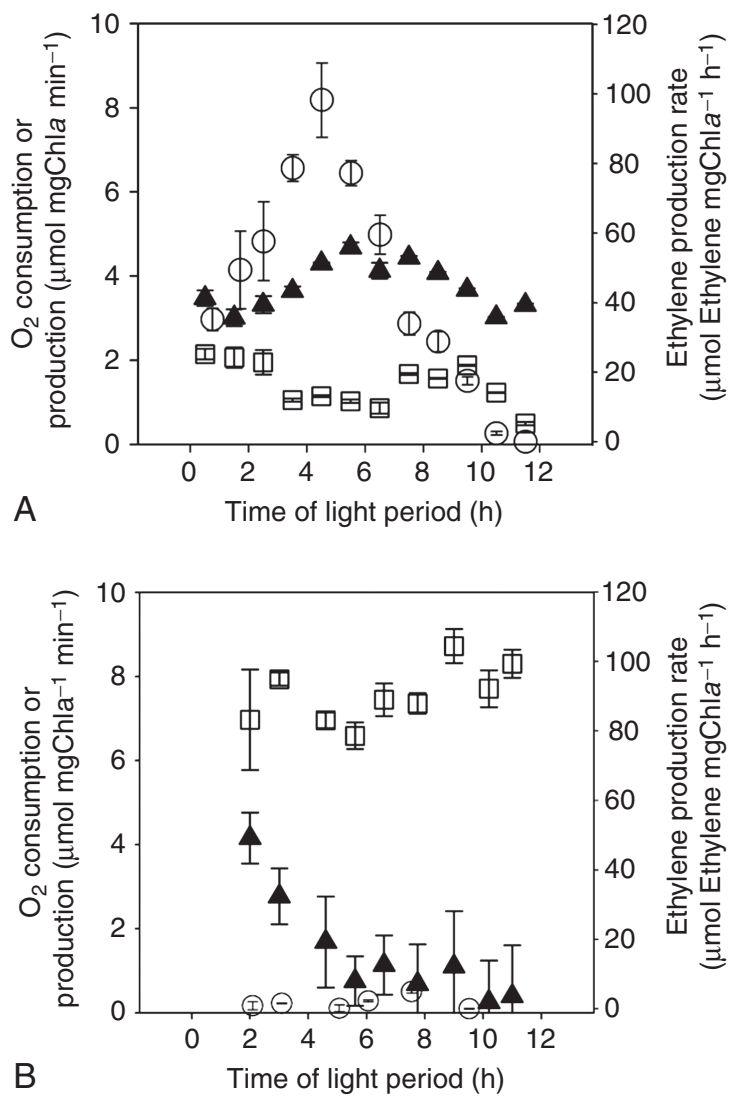

f0040 Figure 35.4 Time course of oxygen production $(\square)$, consumption $(\Delta)$ and acetylene reduction (O) during the photoperiod in Trichodesmium sp. IMS 101 grown with $\mathrm{N}_{2}$ (A) and nitrate (B) as nitrogen sources. Error bars are \pm 1 standard deviation.

cultures (with negligible nitrogen-fixation), Mehler activity increases with light induction, but quickly drops to low and constant rates (10\% of gross production) through the rest of the photoperiod (Fig. 35.4).

p0330 In Trichodesmium, Mehler activity is essential, as Trichodesmium relies on short term regulation of PSII and nitrogenase activities to separate these functions within a trichome (Berman-Frank et al., 2003). PSII activity is regulated on time scales of 10-15 min and appears to involve the association/disassociation of the light harvesting complex (LHC II) from PSII (Küpper et al., 2004). Nitrogenase activity is also regulated on similar time scales when incubated at different oxygen concentrations, with transcriptional and translational regulation requiring longer time-scales and higher concentrations of exposure (Fig. 35.2). While PSII activity is repressed in $\mathrm{N}_{2}$ fixing cells, the activity of PSI is responsible for net $\mathrm{O}_{2}$ consumption relying on the translocation of reductant for the donor side of PSI and the flux of photons driving the oxidation. Recent observations support this notion. Cultures of Trichodesmium grown under low (5\%) oxygen showed some 
nitrogenase activity during the night; this activity was absent in controls (21\%) and in high (50\%) oxygen cultures (Küpper et al., 2004). The lack of Mehler activity at night in the controls $(21 \%)$ and in the high oxygen cultures may thus reduce the total possible oxygen consumption and prevent nitrogenase activity. At lower $\mathrm{O}_{2}$ concentrations, $\mathrm{N}_{2}$ fixation can proceed in darkness because the respiratory rates are sufficient to consume $\mathrm{O}_{2}$.

\subsection{Biological feedbacks to the global N, C, and $\mathrm{O}$ cycles}

Oxygen-consuming pathways, including the Mehler reaction, deliver a positive feed-back to nitrogenase and nitrogen fixation by reducing the concentrations of molecular and reactive oxygen that inhibit the enzyme. Yet the presence of oxygen is essential as respiratory pathways provide the required substrates for subsequent nitrogen assimilation. Thus, oxygen concentrations will exert both a positive and negative feedback towards adaptations at the organism-scale, which reflect a compromise of opposing metabolic requirements. At the molecular/biochemical scale, oxygen concentrations impose an upper limit on the nitrogenase enzyme for all types of cyanobacterial diazotrophs. Whether the regulation is at the level of transcription, translational, or metabolic activity, depends on the concentration and duration of inhibition by oxygen. Chronic inhibition of nitrogenase at PAL of $\mathrm{O}_{2}$ imposes a metabolic inefficiency that reflects an extraordinarily slow tempo of evolution for this critical biogeochemical process. The high conservation within the primary sequence of nif genes suggests that the evolutionary risks associated with modifying nitrogenase outweigh the costs of its production. Nitrogenase is analogous to other core metabolic proteins, such as the reaction center protein of photosystem II, D1 and ribulose 1,5 bisphosphate carboxylase/oxygenase (Rubisco), which also operate at a fraction of their capacities under ambient atmospheric conditions or undergo extremely high rates of turnover as a result of posttranslational damage. The inhibition of all of these proteins, either directly by elevated $\mathrm{O}_{2}$, or indirectly through reactive oxygen species, potentially exerts a strong biological control on the upper bound of the concentration of the gas in Earth's atmosphere, leading to metabolic and biogeochemical inefficiency in $\mathrm{N}_{2}$ fixation. The inefficiency imposes a major elemental taxation on diazotrophic cyanobacteria, both in the costs of protein synthesis and in the scarce trace elements, such as iron, which has, in turn, led to a global limitation of fixed nitrogen in the contemporary oceans (Falkowski, 1997).

p0350 We extended and applied the systems-analysis based approach of Beerling and Berner (Beerling and Berner, 2005) to the feedbacks between (aquatic) nitrogen fixation and the cycles of carbon and oxygen (Fig. 35.5). While the role of sustained forest fires in maintaining PAL of oxygen (Lenton and Watson, 2000; Watson et al., 1978) is currently debated (Wildman et al., 2004), nitrogen fixation (via the evolutionary sensitivity of nitrogenase) acts as an additional control, limiting the upper concentration of oxygen in the atmosphere. The reduction of nitrogen-fixation due to high oxygen concentrations could lead to a decline in both diazotrophic and total aquatic primary productivity (with parallel declines in the terrestrial biomass due to higher photorespiration under high oxygen), and to reduced rates of organic burial. 


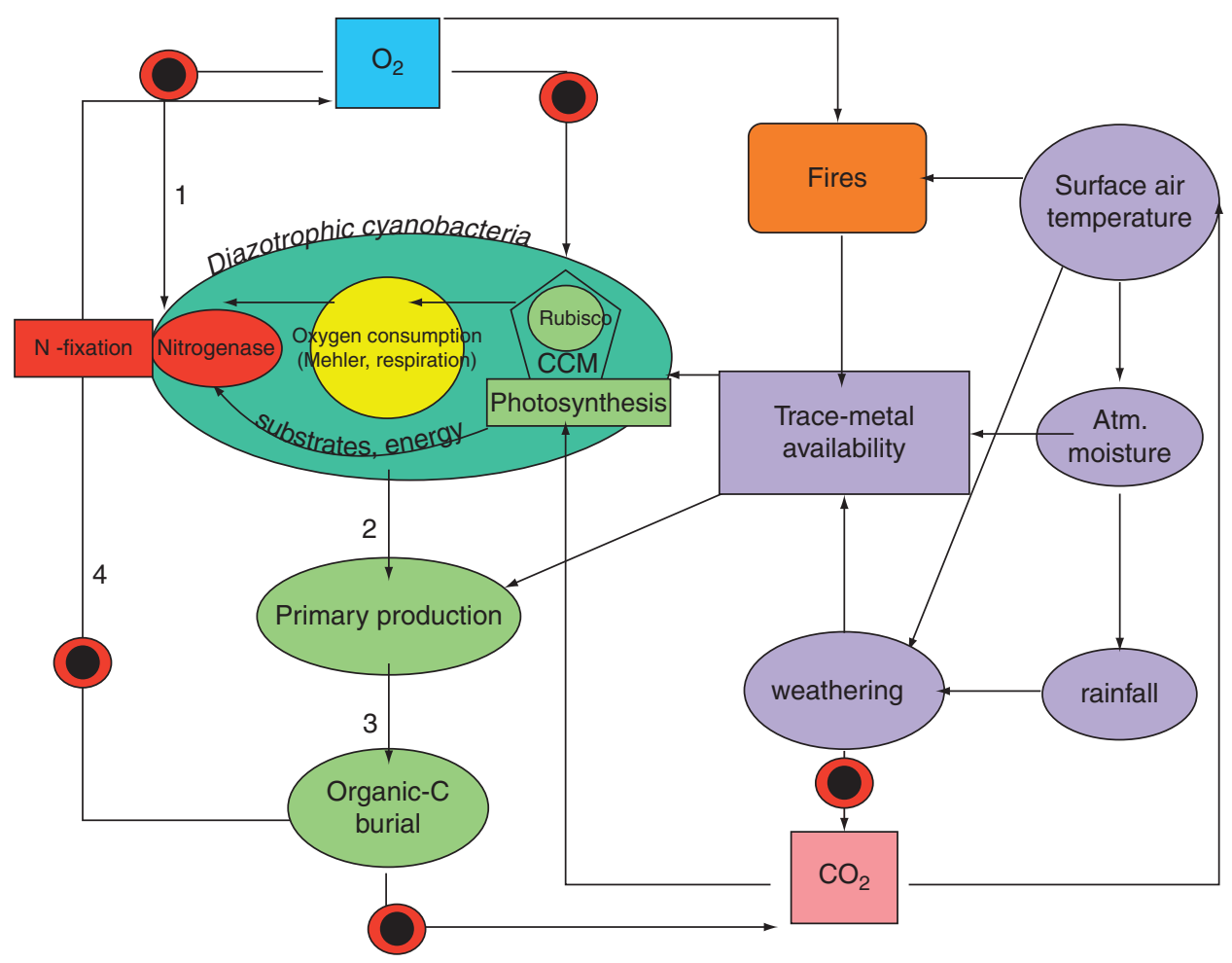

f0050 Figure 35.5 Simplified systems analysis diagram of the feedbacks between nitrogen fixation (mainly by aquatic cyanobacterial diazotrophs) and the oxygen and carbon cycles. Plain arrows show direct responses while arrows with bull's-eyes illustrate inverse effects. The feedback loop is designated by numbers adjacent to path. Diagram modified from Beerling and Berner (2005).

Lower burial rates would lead to an increase in both oxygen and in atmospheric $\mathrm{CO}_{2}$. If oxygen concentrations are maintained at PAL or slightly lower (see Fig. 35.2D), nitrogen fixation is sufficient to drive high total primary production and higher burial rates, and a negative feedback to both $\mathrm{C}$ and $\mathrm{O}$ concentrations (Fig. 35.5).

\section{Sensitivity of the Nitrogen, Carbon, and Oxygen Cycles to Climate Change}

p0360

Biological feedbacks into the global nitrogen and oxygen cycles are intricately dependant on climate patterns and oceanic circulation which also influence trace metal availability in the upper ocean. In this section we explore future scenarios in the oceanic nitrogen, carbon and oxygen cycles due to shifts in aeolian iron availability, variations in climate, and ocean circulation. 


\subsection{Aeolian iron and stratification of the surface mixed layer in the future}

p0370 The major source of $\mathrm{Fe}$ in the surface waters of several large ocean regions is the aeolian dust transported from the continents (Duce and Tindale, 1991; Fung et al., 2000; Jickells, 1995). Yet the evidence for the relative importance of aeolian sources versus in situ iron supply by upwelling waters from depths is unclear (Coale et al., 1996). The distribution of aeolian Fe varies strongly with the seasons and from one ocean region to another. The predominant fraction of the Fe inputs enters the oceans in the Northern Hemisphere, where the high Fe fluxes are primarily concentrated in low and mid-latitudes (Gao et al., 2001). These are characterized by disproportionate seasonal flux rates, with summer Fe fluxes approximately twice those of winter fluxes (Gao et al., 2001). This non-uniform distribution feature is largely reflected by the distribution of dust sources (Ginoux et al., 2001; Zender et al., 2003). The current estimate of the total Fe deposition to the ocean is $\sim 14 \times 10^{12}$ g year $^{-1}$, which includes substantial uncertainties. The major processes that control the delivery of aeolian Fe to the ocean are dry deposition by gravitational settling of particles, turbulence in the surface layer of the atmosphere, and wet deposition through precipitation scavenging. Any variation in the strength and distribution of dust sources, and removal processes caused by climate change and land use, could affect dust emissions (Tegen et al., 2004) and consequent delivery of aeolian iron to the ocean.

p0380 One example is the increasing concentrations of atmospheric $\mathrm{CO}_{2}$ and enhanced global temperatures which have altered the global hydrological cycle. This is reflected by changes in precipitation patterns that may have profound impacts on dust emissions and subsequent deposition to the oceans. Over the past century there has been a global increase in rainfall over land (Dai et al., 1997). Enhanced precipitation over desert regions, in particular, has been considered as a negative feedback to desertification (Miller et al., 2004). The increased rainfall could directly impact the emissions of dust through altering soil moisture (aridity) in the source regions and dust burden in the atmosphere and, consequently, affect the concentrations of dust over the oceans. Observations made at Barbados in the tropical North Atlantic indicate that variations in dust concentrations from 1965 to 1998 were inversely correlated with rainfall in the Soudano-Sahel region in Africa (Prospero and Lamb, 2003). This finding suggests that atmospheric dust loading over the ocean is sensitive to the strength of precipitation in the dust source regions; therefore, any increases in precipitation and rising concentrations of atmospheric $\mathrm{CO}_{2}$ may contribute to decreased aridity and a possibly less dusty atmosphere in the future (Mahowald and Luo, 2003).

p0390 Increased precipitation over the oceans may, however, increase the supply of a more "bioavailable," dissolved aeolian Fe via wet deposition. During long range transport, dust particles undergo heterogeneous reactions at gas-solid-liquid interfaces involving pollution-derived substances that may lead to the increased solubility of aeolian Fe (Dentener et al., 1996; Meshidzke et al., 2003; Underwood et al., 2001). Photochemical reduction in more acidic cloud waters and precipitation promote dissolution of $\mathrm{Fe}$ in dust, leading to the production of soluble Fe (II) (Siefert et al., 
1999; Zhu et al., 1997; Zhuang et al., 1992). These natural processes potentially increase the amount of dissolved Fe in precipitation beyond the Fe solubility of a few percent directly measured from leaching of dry dust particles. Gao et al. (Gao et al., 2003) suggest that the annual input of dissolved Fe by wet deposition accounts for $4-30 \%$ of the total aeolian Fe fluxes to the ocean. Hand et al, (Hand et al., 2004) reported that soluble iron associated with aerosols over the Atlantic and Pacific ranged from $0-45 \%$ in the $\mathrm{PM}_{2.5}$ mode (particulate mass less than $2.5 \mu \mathrm{m}$ diameter) and $0-87 \%$ in the coarse mode. These findings reveal that soluble iron could be a significant fraction of the total aeolian Fe entering the surface seawaters. Thus, increasing the supply of soluble aeolian Fe in the oceans through wet deposition may cause natural iron fertilization and induction of blooms by diazotrophic and other Fe-limited photosynthetic populations. As such, variations in precipitation distributions, or changes in hydrological cycles caused by global warming, could alter carbon cycles in the ocean and contribute to the future climate change. The non-linear response of critical environmental factors over the land and oceans has restricted the characterization and predictive power of how precipitation and landuse patterns influence dust generation and subsequent aeolian Fe deposition to the oceans.

p0400 Changes in ocean stratification may further affect the degree of aeolian $\mathrm{Fe}$ demand by marine biota and the subsequent $\mathrm{CO}_{2}$ fluxes (Le Quere et al., 2003). Intensified stratification in the upper ocean due to global warming could become more resistant to mixing by surface wind and prevent the flux of nutrients from deep waters to the surface layer (Sarmiento et al., 1998). This weakened mixing could also reduce the amount of recycled Fe brought from the deep ocean to the surface layer and, consequently, the supply of aeolian Fe to production in the surface ocean could be more critical in the future. This situation may occur both in the high-nutrient low-chlorophyll (HNLC) waters and also in the oligotrophic gyres, where there may be co-limitation of production by iron and phosphorous (Mills et al., 2004). In the eastern subtropical North Atlantic, where the impact of Saharan dust input is strong, utilization of nitrate supplied from dust deposition could be enhanced in the strongly stratified mixed layer during the late summer-fall period, thereby promoting phytoplankton growth (Neuer et al., 2004). Although primary productivity in the Sargasso Sea is often suggested to be phosphorus-limited, as the concentrations of dissolved inorganic phosphate in the surface waters are low (Wu et al., 2000), results from nutrient-addition bioassays in the tropical North Atlantic indicate that nitrogen fixation in this region is co-limited by iron and phosphorus (Mills et al., 2004). This finding suggests that even in a region where dust deposition is high and the amount of aeolian Fe should be sufficient, the rates of nitrogen fixation by high-Fe demanding organisms such as Trichodesmium spp. are still controlled by the supply of iron.

p0410 The combined effects of warming air temperatures and of enhanced stratification in the upper ocean may thus promote the dissolution of iron in dust and its subsequent bio-availability in the surface seawaters, possibly enhancing nitrogen fixation and export production. Future aeolian Fe input to the ocean may increase due to desertification enhanced by human activities or decrease by altered hydrological cycles. These interactions and feedbacks could certainly play important roles in future nutrient and carbon cycles in the ocean. 


\subsection{Interactions of the oxygen and nitrogen cycles: Nitrification and denitrification}

p0420 Changes in the ocean nitrogen budget linked to climate change have been discussed by several authors (Altabet et al., 1995; Broecker and Henderson, 1998; Falkowski, 1997; Ganeshram et al., 1995). The coupling of the nitrogen and oxygen cycles via nitrification and denitrification has implications for the long-term chemical evolution of the ocean and atmosphere, the variations in the oceans' nitrogen inventory, and the nitrogen limitation of marine ecosystems over centennial and longer timescales. Yet, the interactions and feedbacks of the coupled nitrogen and oxygen cycles are not clearly understood. Consider a reduction of nitrogen fixation leading to a global decline in the fixed nitrogen budget of the ocean, increasing nitrogen limitation and reducing total export production. In response, deep ocean respiration decreases and the low oxygen zones shrink along with the integrated rate of denitrification. While there is the possibility for a stabilizing feedback(Codispoti, 1989), the processes of nitrogen fixation and denitrification are spatially (and temporally) disconnected; the former occurs predominantly in the surface, subtropical oceans while the latter occurs in the low oxygen zones of the water column and sediments (Fig. 35.1). Thus the rate of accumulation or the loss of nitrogen in the ocean must also be regulated by the processes of physical transport by which these regions are connected. In the modern ocean, the transport timescale between the subtropical Atlantic, a region of significant nitrogen fixation, and the low oxygen waters of the mid-depth Pacific basin, is on the order of hundreds of years leading to the potential for delayed responses in the feedback loop (e.g. Gruber, 2004) and even to oscillatory behavior. A highly idealized box model of the coupled nitrogen and oxygen cycles (Fennel et al., 2005) suggests complex interactions (see following section) and illustrates how these interactions were likely critical in the development of global biogeochemical cycles on the early Earth. Factoring in possible links to the carbon pumps, climate and the global iron cycle suggests even richer, and more complex, possibilities for interactions of climate and biogeochemical cycles (e.g. (Falkowski, 1997).

\subsection{Ocean circulation and the global ocean cycles of nitrogen, oxygen and carbon}

p0430 Ocean models forced by warmer atmospheric climates and coupled climate models in global warming scenarios suggest that weakened atmospheric temperature gradients and increased hydrological cycle might weaken the ventilation of the deep ocean (e.g. Zhang et al., 2001) and expand the regions of well-stratified, subtropical surface waters (e.g. (Sarmiento et al., 2004). Consider the oceanic nitrogen cycle as represented simply in Fig. 35.6. Nitrogen is supplied to the surface ocean by ocean circulation, from depth, or by fixation in the surface. Depending upon the nature of the ecosystem and its efficiency at recycling, some fraction, $\mathrm{N}_{\text {bio }}$, of the deep ocean nitrogen, $\mathrm{N}_{\mathrm{d}}$, is brought to depth through biological export of organic matter and remineralization. The remaining fraction, or the pre-formed nitrogen $\mathrm{N}_{\text {pre }}$, is brought to depth by physical advection or mixing from the surface layer. In regions 

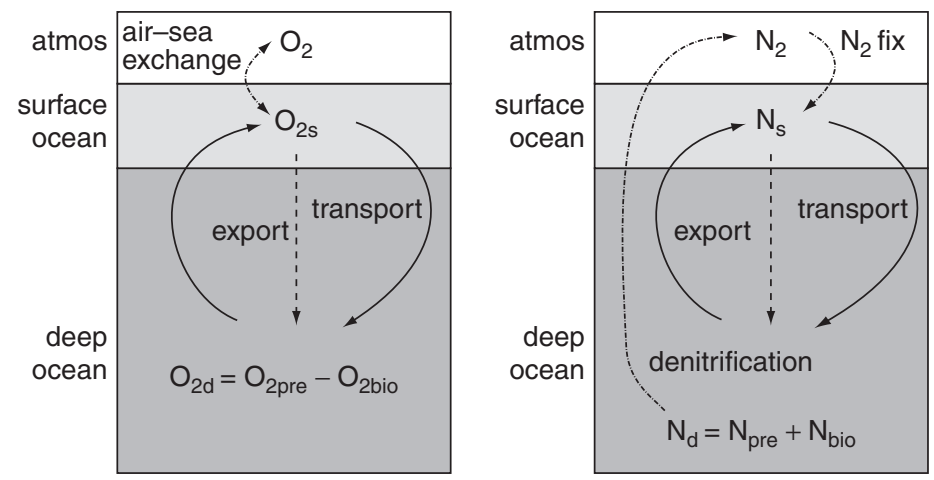

f0060 Figure 35.6 Simplified schematic views of the oceanic nitrogen and oxygen cycles. $\mathrm{N}_{d}$ and $\mathrm{O}_{2 \mathrm{~d}}$ are the deep ocean dissolved inorganic nitrogen and dissolved oxygen concentrations respectively, $\mathrm{N}_{\text {pre }}$ and $\mathrm{O}_{2 \text { pre }}$, are the preformed nitrogen and oxygen concentrations, and $\mathrm{N}_{\text {bio }}$ and $\mathrm{O}_{2 \text { bio }}$ are the contributions to deep ocean concentrations due to the remineralization of exported organic matter. $\mathrm{N}_{\mathrm{s}}$ and $\mathrm{O}_{2 \mathrm{~s}}$ are the concentrations of dissolved inorganic nitrogen and dissolved oxygen in the surface mixed-layer of the ocean. Exported organic matter (really export of "oxygen demand"indicated by the minus sign) is respired in the deep ocean, providing a source of dissolved inorganic nitrogen and a sink of dissolved oxygen.

of low oxygen (including pore waters), denitrification and subsequent processes ultimately lead to a return to dinitrogen gas, and to nitrogen loss from the oceans.

p0440 The warming of the surface ocean will weaken the overturning circulation leading to shallower mixed-layer. Slower overturning suggests a longer residence time for waters in the surface, perhaps increasing the role of biological export relative to physical transport, favoring $\mathrm{N}_{\text {bio }}$ over $\mathrm{N}_{\text {pre }}$. In addition, a coincident warming of the surface waters and reduction of turbulent mixing in the surface mixed-layer might favor diazotrophs such as Trichodesmium (Capone, 2001), enhance nitrogen fixation and work to increase the oceanic nitrogen budget, perhaps relieving nitrogen limitation. Consider, however, the coupled oxygen cycle. Shallower mixing and warming of the surface waters will reduce the physical supply of oxygen to the deep ocean and decrease the solubility of oxygen in the ventilated waters $\left(\mathrm{O}_{2 \text { pre }}\right.$ decreases) (which may further enhance nitrogenase activity and nitrogen-fixing species but will reduce productivity of other phytoplankton). Consequently, deep ocean oxygen concentrations, $\mathrm{O}_{2 \mathrm{~d}}$, will likely decrease under such conditions, increasing the extent of regions of very low oxygen concentration in the water column (Zhang et al., 2001) and pore waters. In consequence, the global flux of denitrification is also likely to increase in response. The net effect of such a climate change on the oceanic nitrogen budget and productivity is not yet clear.

p0450 We examined the steady state response of the fully dynamic ocean nitrogen and oxygen cycles in our box model (see section Ib, Fennel et al., 2005) and an atmospheric mixing ratio of oxygen at $20 \%$ to prescribed variations in the ocean overturning, efficiency of nitrogen fixation and mean ocean phosphate loading. Starting from modern ocean conditions under which the oceanic N:P ratio is close to 16 , varying the rate of overturning between 10 and 30 Sverdrups does little to the ocean nitrogen inventory, or $\mathrm{N}: \mathrm{P}$, though the timescale for adjustment increases as overturning 
decreases. Changing the efficiency of nitrogen fixation, perhaps interpreted as reflecting changes in upper ocean stratification, has some interesting and counter-intuitive consequences; since the modern ocean has an N:P ratio close to 16, increasing the efficiency of nitrogen fixation does not significantly enhance the nitrogen budget, as the model assumes diazotrophs are not competitive unless nitrogen is limiting. However, for conditions where oceanic N:P is somewhat lower than 16 , increasing nitrogen fixation can decrease the fixed nitrogen inventory of the deep ocean by enhancing export production, reducing deep ocean oxygen and increasing the rate of denitrification. Increasing the oceanic phosphorus inventory above today's values also reduces $\mathrm{N}: \mathrm{P}$ through a similar mechanism. These model explorations suggest there are critical nonlinear interactions of between the $\mathrm{C}, \mathrm{N}, \mathrm{O}$ and $\mathrm{P}$ cycles which remain to be elucidated.

\section{s0130 3.4. Implications for the global carbon cycle}

p0460 What are the implications of such changes in the nitrogen cycle for the global carbon cycling and atmospheric $\mathrm{pCO}_{2}$ ? A biologically mediated net exchange of $\mathrm{CO}_{2}$ between the atmosphere and ocean can be brought about by changing the oceanic inventory of one or more limiting nutrients (Falkowski et al., 2003). If fixed inorganic nitrogen is limiting, then how sensitive is the atmospheric exchange of $\mathrm{CO}_{2}$ with the ocean to a change in the inventory of fixed inorganic nitrogen. To do this, we examined the effect of changing the nitrogen inventory (through biological fixation) in a coupled biogeochemical model. Following the treatment of the nitrogen and oxygen concentrations in the deep ocean, we may describe the ocean reservoir of dissolved inorganic carbon $\left(\mathrm{DIC}_{\mathrm{d}}\right)$ as the sum of preformed $\left(\mathrm{DIC}_{\text {pre }}\right)$ and biological components $\left(\mathrm{DIC}_{\mathrm{bio}}\right)$ :

$$
\mathrm{DIC}_{\mathrm{d}}=\mathrm{DIC}_{\text {pre }}+\mathrm{DIC}_{\mathrm{bio}}
$$

p0470 Here, the preformed pool includes contributions from the saturation concentration and the degree of disequilibrium at the point of subduction. The biological fraction has contributions from both soft-tissue and carbonate pumps (Volk and Hoffert, 1985). Following Brewer (Brewer, 1978) we may, as a first approximation, interpret the soft-tissue contribution to be related to the biological fraction of nitrogen by a fixed, Redfieldian stoichiometry:

$$
\mathrm{DIC}_{\mathrm{bio}}=R_{\mathrm{CN}} \mathrm{N}_{\mathrm{bio}} \text {. }
$$

p0480 If the ocean-atmosphere loading of carbon is fixed then, given these simplistic assumptions, enhancing the oceanic nitrogen budget and export production would lead to an enhancement of the oceans biological carbon pool at the expense of the atmosphere, reducing atmospheric $p \mathrm{CO}_{2}$ in proportion to the change in DIC according to the buffer factor, B:

$$
\mathrm{d} p \mathrm{CO}_{2} / p \mathrm{CO}_{2} \sim \mathrm{BdDIC} / \mathrm{DIC}
$$

(e.g. Bolin and Erickson, 1959) where $B \sim \mathrm{O}(10)$. 
p0490 Accordingly, let us consider some climate change process which leads to an increase in fixed inorganic $\mathrm{N}$ by $1 \mathrm{~mol} \mathrm{~L}^{-1}$ in the ocean interior, $\mathrm{N}_{\mathrm{d}}$. Studies of the contemporary ocean suggest that the biological contribution $\mathrm{N}_{\text {bio }} \sim 0.3 \mathrm{~N}_{\mathrm{d}}$. Assuming this fraction stays constant and $R_{\mathrm{CN}} \sim 6$, this implies a corresponding $2 \mathrm{M}$ increase in $\mathrm{DIC}_{\mathrm{d}}$. The buffering relationship (2.5) suggests a modest associated decrease in atmospheric $p \mathrm{CO}_{2}$ (relative to $280 \mathrm{ppmv}$ ) of about $3 \mathrm{ppmv}$ in the steady state (see Ito and Follows, 2004) for a more detailed analysis). If all of the extra nitrogen is in the biological fraction, the sensitivity of atmospheric $\mathrm{CO}_{2}$ to the mean ocean nitrogen concentration could be as much as $10 \mathrm{ppmv}$ per micromole, relative to the pre-industrial state. It should be noted that this argument assumes no impact on the preformed component, $\mathrm{DIC}_{\text {pre }}$. It also assumes a fixed ocean-atmosphere carbon budget. However, modifications of the deep ocean carbonate system will ultimately lead to interactions with the sedimentary calcium carbonate reservoir, dampening the impact on atmospheric pCO2 (e.g. Bolin and Eriksson, 1959).

\section{Summary and Conclusions}

p0500

The history of Earth can be broadly divided into two "super eons." The first 2.2 billion years were marked by biological innovation and experimentation, during which time all the major metabolic pathways evolved in prokaryotes. One of these pathways, oxygenic photosynthesis, would subsequently, over the second half of Earth's history, give rise to aerobic metabolism, and ultimately permit the evolution of multicellular eukaryotes. The shift from mildly reducing to strongly oxidizing conditions was, beyond doubt, the most profound transition since the origin of life itself. Our analysis suggests that feedbacks between $\mathrm{C}, \mathrm{N}$, and $\mathrm{O}$ cycles helped prevent the oxidation of Earth in the Paleoproterozic. This stabilizing feedback, which was ultimately over-ridden, led to the contemporary nitrogen cycle where nitrate, rather than ammonium, was the stable form of fixed inorganic nitrogen in the oceans. Barring some minor changes in the trace element composition in nitrogenases, the core proteins remained essentially unchanged following the transition to an oxidized atmosphere. In the contemporary ocean, approximately $20-30 \%$ of nitrogenase activity is inhibited at any moment in time by $\mathrm{O}_{2}$. This inhibition results in a negative feedback which constrains the upper level of $\mathrm{O}_{2}$ on Earth (Figs. 35.2 and 35.5).

Three central aspects of cyanobacterial nitrogen fixation remain curious. First, although some trace elements have been altered in the evolution of nitrogenases, the core proteins have remained virtually unchanged. In effect, nitrogenase, like RuBisCO, is a "frozen metabolic accident" (Shi et al., 2005). Either there is no substitute for the basic iron-sulfur cluster motif, or protein-protein interactions have severely constrained the evolutionary trajectory of this enzyme complex, or both. Whatever the reason, all nitrogenases are irreversibly inhibited by oxygen-and cyanobacteria are the only oxygenic photoautotrophs that contain the gene. Second, while there is abundant evidence of lateral transfer of nitrogenase genes between prokaryotes, in the endosymbiotic appropriation of cyanobacteria into heterotrophic hosts to photosynthetic eukaryotes, nitrogenases were lost. Indeed, there is no known 
eukaryote that contains an endogenous functional nitrogenase. It is not apparent whether this deficiency is genetically insurmountable, but it is clear that (under present conditions) it made most aquatic eukaryotes dependent on cyanobacteria for fixed inorganic nitrogen. In oligotrophic subtropical and tropical oceans large chainforming diatoms are found in association with the endosymbiotic heterocystous cyanobacterium, Richelia intracellularis that contribute significant amounts of fixed $\mathrm{N}$ to some systems (Capone et al., 1997; Carpenter et al., 1999; Janson et al., 1999; Venrick, 1974). Yet, given the above dependency, the low diversity and limited biomass of endosymbiotic nitrogen fixing cyanobacteria harbored in eukaryotic host cells seems curious. Third, although free-living heterocystous cyanobacteria are abundant in lakes and brackish water ecosystems, they appear to be rare in the open ocean (Carpenter and Janson, 2001). Recent work demonstrates the advantage of heterocysts in lower temperature and salinities compared to Trichodesmium types, which dominate in the tropical oceans (Staal et al., 2003b). Yet, it is not clear why this, or some other biological innovation which facilitates nitrogen fixation under relatively high oxygen concentrations, is rare in temperate and polar oceanic ecosystems.

Clearly these issues will be the focus of research efforts over the next few decades because they lie at the heart of a fundamentally applied problem: why have we not been able to genetically engineer plants that feed and serve humans with the capability of fixing their own nitrogen? Should we overcome that major hurdle, we will have made a major transition in the impact of humans on the chemistry of Earth and its oceans.

\section{REFERENCES}

Adams, D. G. (2000). Heterocyst formation in cyanobacteria. Curr. Opin. Microbiol. 3, 618-624.

Altabet, M. A., Francois, R., Murray, D. W., and Prell, W. L. (1995). Climate-related variations in denitrification in the Arabian Sea from sediment ${ }^{15} \mathrm{~N} /{ }^{14} \mathrm{~N}$ ratio. Nature 373, 506-509.

Anbar, A. D., and Knoll, A. H. (2002). Proterozoic ocean chemistry and evolution: A bioinorganic bridge. Science 297, 1137-1142.

Arnold, G. L., Anbar, A. D., Barling, J., and Lyons, T. W. (2004). Molybdenum isotope evidence for widespread anoxia in mid-proterozoic oceans. Science 304, 87-90.

Beerling, D. J., and Berner, R. A. (2005). Feedbacks and the coevolution of plants and atmospheric $\mathrm{CO}_{2}$. Proc. Natl. Acad. Sci. U S A. 102, 1302-1305.

Bekker, A., Holland, H. D., Wang, P.-L., Rumble, D., Stein, H. J., Hannah, J. L., Coetzee, L. L., and Beukes, N. J. (2004). Dating the rise of atmospheric oxygen. Nature 427, 117-120.

Ben-Porath, J., Carpenter, E. J., and Zehr, J. P. (1993). J. Phycol. 29, 806.

Bergman, B., Gallon, J. R., Rai, A. N., and Stal, L. J. (1997). $\mathrm{N}_{2}$ fixation by non-heterocystous cyanobacteria. FEMS Microbiol. Rev. 19, 139-185.

Berman-Frank, I., Cullen, J. T., Shaked, Y., Sherrell, R. M., and Falkowski, P. G. (2001). Iron availability, cellular iron quotas, and nitrogen fixation in Trichodesmium. Limnol. Oceanogr. 46, 1249-1260.

Berman-Frank, I., Lundgren, P., and Falkowski, P. (2003). Nitrogen fixation and photosynthetic oxygen evolution in cyanobacteria. Res. Microbiol. 154, 157-164.

Berner, R. A. (1984). Sedimentary pyrite formation: An update. Geochim. Cosmochim. Acta 48, 605-615.

Bjerrum, C. J., and Canfield, D. E. (2002). Ocean productivity before about 1.9 Gyr ago limited by phosphorus adsorption onto iron oxides. Nature 417, 159-162.

Bohme, H. (1998). Regulation of nitrogen fixation in heterocyst-forming cyanobacteria. Trends Plant Sci. 3, 346-351. 
Bolin, B., and Eriksson, E. (1959). Changes in the carbon dioxide content of the atmosphere and the sea due to fossil fuel combustion. "The Atmosphere and the Sea in Motion". Rockefeller Institute Press, New York, pp. 130-142.

Brewer, P. G. (1978). Direct observation of the oceanic $\mathrm{CO}_{2}$ increase. Geophys. Res. Lett. 5, 997-1000.

Brocks, J. J., Logan, G. A., Buick, R., and Summons, R. E. (1999). Archean molecular fossils and the early rise of eukaryotes. Science 285, 1033-1036.

Broda, E., and Pesheck, G. A. (1983). Nitrogen fixation as evidence for the reducing nature of the early atmosphere. Biosystems 16, 1-8.

Broecker, W. S., and Henderson, A. G. M. (1998). The sequence of events surrounding termination II and their implications for the cause of glacial-interglacial $\mathrm{CO}_{2}$ changes. Paleoceanography 13, 352-364.

Burgess, B. K., and Lowe, D. J. (1996). Mechanism of molybdenum nitrogenase. Chem. Rev. 96, 2983-3011.

Canfield, D. E. (1998). A new model for proterozoic ocean chemistry. Nature 396, 450-453.

Canfield, D. E., and Teske, A. (1996). Late proterozoic rise in atmospheric oxygen concentration inferred from phylogenetic and sulphur-isotope studies. Nature 382, 127-132.

Capone, D. G. (2001). Marine nitrogen fixation: What's the fuss? Curr. Opin. Microbiol. 4, 341-348.

Capone, D. G., Zehr, J. P., Paerl, H. W., Bergman, B., and Carpenter, E. J. (1997). Trichodesmium, a globally significant marine cyanobacterium. Science 276, 1221-1229.

Carpenter, E. J., and Janson, S. (2001). Anabaena gerdii sp. nov., a new planktonic filamentous cyanobacterium from the South Pacific Ocean and Arabian Sea. Phycologia 40, 105-110.

Carpenter, E. J., Montoya, J. P., Burns, J., Mulholland, M. R., Subramaniam, A., and Capone, D. G. (1999). Extensive bloom of a $\mathrm{N}_{2}$-fixing diatom/cyanobacterial association in the tropical Atlantic Ocean. Mar. Ecol. Prog. Ser. 185, 273-283.

Chandler, F. W. (1980). Proterozoic redbed sequences of Canada. Can. Geol. Surv. Bull .

Coale, K. H., Fitzwater, S. E., Gordon, R. M., Johnson, K. S., and Barber, R. T. (1996). Control of community growth and export production by upwelled iron in the equatorial Pacific Ocean. Nature $379,621-624$.

Codispoti, L. A. (1989). Phosphorus versus nitrogen limitation of new (export) production. In "Productivity of the Ocean: Present and Past" (Berger, W., Smetacek, V., and Wefer, G., eds.). Wiley, New York, pp. 377-394.

Dai, A., Fung, I., and Al, E. (1997). Surface observed global land precipitation variations during 19001988. J. Climate 10, 2943-2962.

Dentener, F. J., Carmichael, G. R., Zhang, Y., Lelieveld, J., and Crutzen, P. J. (1996). Role of mineral aerosol as a reactive surface in the global troposphere. J. Geophys. Res. 101, 869-889.

Des Marais, D. J., Strauss, H., Summons, R. E., and Hayes, J. M. (1992). Carbon isotope evidence for the stepwise oxidation of the proterozoic environment. Nature 359, 605-609.

Dominic, B., Chen, Y.-B., and Zehr, J. P. (1998). Cloning and transcriptional analysis of the nifUHDK genes of Trichodesmium sp. IMS101 reveals stable nifD, nifDK, and nifK transcripts. Microbiology 144, 3359-3368.

Duce, R. A., and Tindale, N. W. (1991). Atmospheric transport of iron and its deposition in the ocean. Limnol. Oceanogr. 36, 1715-1726.

Durner, J., Bohm, I., Knorzer, O. C., and Boger, P. (1996). Proteolytic degradation of dinitrogenase reductase from Anabaena variabilis (ATCC 29413) as a consequence of ATP depletion and impact of oxygen. J. Bacteriol. 178, 606-610.

Ernst, A., Liu, Y.-D., Reich, S., and Boger, P. (1990). Diurnal modification in the cyanobacterium Anabaena variabilis. Bot. Acta 103, 183-189.

Falkowski, P. G. (1997). Evolution of the nitrogen cycle and its influence on the biological sequestration of CO2 in the ocean. Nature 387, 272-275.

Falkowski, P. G. (2001). Biogeochemical cycles. In "Encyclopedia of Biodiversity". Academic Press, New York, pp. 437-453.

Falkowski, P. G., Laws, E. A., Barber, R. T., and Murray, J. W. (2003). Phytoplankton and their role in primary, new, and export production. In "Ocean Biogeochemistry: The Role of the Ocean Carbon Cycle in Global Change" (Fasham, M. J. R., ed.). IGBP. 
Fani, R., Gallo, R., and Lio, P. (2000). Molecular evolution of nitrogen fixation: The evolutionary history of the nifD, nifK, nifE, and nifN genes. J. Mol. Evol. 51, 1-11.

Farquhar, J., Bao, H., and Thiemens, M. (2000). Atmospheric influence of earth's earliest sulfur cycle. Science 289, 756-758.

Fay, P. (1992). Oxygen relations of nitrogen fixation in cyanobacteria. Microbiol. Rev. 56, 340-373.

Fennel, K., Follows, M., and Falkowski, P. G. (2005). The co-evolution of the nitrogen, carbon and oxygen cycles in the proterozoic ocean. Am. J. Sci. 305, 526-545.

Fung, I., Meyn, S., Tegen, I., Doney, S., John, J., and Bishop, J. (2000). Iron supply and demand in the upper ocean. Global Biogeochem. Cycles 14, 281-295.

Gallon, J. R. (1992). Reconciling the incompatible: $\mathrm{N}_{2}$ fixation and oxygen. New Phytol. 122, 571-609.

Gallon, J. R. (2001). $\mathrm{N}_{2}$ fixation in phototrophs: Adaptation to a specialized way of life. Plant Soil 230, 39-48.

Gallon, J. R., Pederson, D. M., and Smith, G. D. (1993). The effect of temperature on the sensitivity of nitrogenase to oxygen in the cyanobacteria Anabaena cylindrica (Lemmermann) and Gloeothece (Nageli). New Phytol. 124, 251-257.

Ganeshram, R. S., Pedersen, T. F., Calvert, S. E., and Murray, J. W. (1995). Large changes in oceanic nutrient inventories from glacial to interglacial periods. Nature 376, 755-758.

Gao, Y., Kaufman, Y. J., Tanre, D., Kolber, D., and Falkowski, P. G. (2001). Seasonal distributions of aeolian iron fluxes to the global ocean. Geophys. Res. Lett. 28, 29-32.

Gao, Y., Fan, S. M., and Sarmiento, J. L. (2003). Aeolian iron input to the ocean through precipitation scavenging: A modeling perspective and its implication for natural iron fertilization in the ocean. J. Geophys. Res. Atmos. 108, 4221.

Ginoux, P., Chin, M., Tegen, I., Prospero, J. M., Holben, B., Dubovik, O., and Lin, S.-J. (2001). Sources and distributions of dust aerosols simulated with the GOCART model. J. Geophys. Res. 106, 20255-220273.

Gruber, N. (2004). The dynamics of the marine nitrogen cycle and its influence on atmospheric $\mathrm{CO}_{2}$. In "The Ocean Carbon Cycle and Climate" (Follows, M., and Oguz, T., eds.). Kluwer, Dordrecht.

Hand, J. L., Mahowald, N. M., Chen, Y., Siefert, R. L., Luo, C., Subramaniam, A., and Fung, I. (2004). Estimates of atmospheric-processed soluble iron from observations and a global mineral aerosol model: Biogeochemical implications. J. Geophys. Res. Atmos. 109, D17205.

Hartnett, H. E., Keil, R. G., Hedges, J. I., and Devol, A. H. (1998). Influence of oxygen exposure time on organic carbon preservation in continental margin sediments. Nature 391, 572-574.

Helman, Y., Tchernov, D., Reinhold, L., Shibata, M., Ogawa, T., Schwarz, R., Ohad, I., and Kaplan, A. (2003). Genes encoding a-type flavoproteins are essential for photoreduction of $\mathrm{O}_{2}$ in cyanobacteria. Curr. Biol. 13, 230-235.

Holland, H. D. (1984). "The Chemical Evolution of the Atmosphere and Oceans." Princeton University Press, Princeton, NJ.

Holland, H. D., and Rye, R. (1997). Evidence in pre-2.2 Ga paleosols for the early evolution of atmospheric oxygen and terrestrial biota: Comment. Geology 25, 857-858.

Ito, T., and Follows, M. J. (2004). Preformed phosphate, soft tissue pump and atmospheric $\mathrm{CO}_{2}$. J. Marine Res. 63, 813-839.

Janson, S., Wouters, J., Bergman, B., and Carpenter, E. J. (1999). Host specificity in the Richeliadiatom symbiosis revealed by hetR gene sequence analysis. Environ. Microbiol. 1, 431-438.

Jickells, T. D. (1995). Amospheric inputs of metals and nutrient to the oceans: The magnitude and effects. Mar. Chem. 48, 199-214.

Jouanneau, Y., Meyer, C. M., and Vignais, P. M. (1983). Regulation of nitrogenase activity through iron protein interconversion into an active and an inactive form in Rhodopseudomonas capsulata. Biochim. et Biophys. Acta (BBA)-Protein Struct. Mol. Enzymol. 749, 318-328.

Kana, T. M. (1992). Oxygen cycling in cyanobacteria with specific reference to oxygen protection in Trichodesmium spp. In "Marine Pelagic Cyanobacteria: Trichodesmium and other diazotrophs" (Carpenter, E. J., ed.). Kluwer, Dordrecht, pp. 29-41.

Kana, T. M. (1993). Rapid oxygen cycling in Trichodesmium thiebautii. Limnol. Oceanogr. 38, 18-24.

Kaplan, A., and Reinhold, L. (1999). CO 2 concentrating mechanisms in photosynthetic microorganisms. Annu. Rev. Plant Physiol. Plant Mol. Biol. 50, 539-570. 
Knoll, A. H. (1996). In "Palynology: Principles and Applications" (Jansonius, J., and MacGregor, D. C., eds.). American Association of Stratigraphic Palynologists Foundation, pp. 51-80.

Küpper, H., Ferimazova, N., Setlik, I., and Berman-Frank, I. (2004). Traffic lights in Trichodesmium. Regulation of photosynthesis for nitrogen fixation studied by chlorophyll fluorescence kinetic microscopy. Plant Physiol. 135, 2120-2133.

Kustka, A., Sanudo-Wilhelmy, S., Carpenter, E. J., Capone, D. G., and Raven, J. A. (2003). A revised estimate of the iron use efficiency of nitrogen fixation, with special reference to the marine cyanobacterium Trichodesmium spp. (Cyanophyta). J. Phycol. 39, 12-25.

Lenton, T. M., and Watson, A. J. (2000). Redfield revisited. 1. Regulation of nitrate, phosphate, and oxygen in the ocean. Global. Biogeochem. Cycle 14, 225-248.

Le Quere, C., Aumont, O., Monfray, P., and Orr, J. (2003). Propagation of climate events on ocean stratification, marine biology, and $\mathrm{CO}_{2}$ : Case studies over the 1979-1999 period. J. Geophys. Res. 108, doi:10.1029/2001JC000920.

Ludden, P. W., and Roberts, G. P. (1995). The biochemistry and genetics of nitrogen fixation by photosynthetic bacteria. In "Anoxygenic Photosynthetic Bacteria" (Blankenship, R. E., Madigan, M. T., and Bauer, C. E., eds.). Kluwer, Dodrecht, pp. 929-947.

Mague, T. H., Mague, F. C., and Holm-Hansen, O. (1977). Physiology and chemical composition of nitrogen-fixing phytoplankton in the central north pacific ocean. Mar. Biol. 41, 213-227.

Mahowald, N. M., and Luo, C. (2003). A less dusty future? Geophys. Res. Lett. 30, doi:10.1029/ 2003 GL01880.

Mehler, A. H. (1951). Studies on reactions of illuminated chloroplasts. II. Stimulation and inhibition of the reaction with molecular oxygen. Arch. Biochem. Biophys. 33, 339-351.

Meshidzke, N., Chameides, W. L., Nenes, A., and Chen, G. (2003). Iron mobilization in mineral dust: Can anthropogenic $\mathrm{SO}_{2}$ emissions affect ocean productivity? Geophys. Res. Lett. 30, doi:10.1029/ 2003 GL018035.

Miller, K. G., Kominz, M. A., Browning, J. V., Wright, J. D., Mountain, G. S., Katz, M. E., Sugarman, P. J., Cramer, B. S., Christie-Blick, N., and Pekar, S. F. (2005). The phanerozoic record of global sea-level change. Science 310, 1293-1298.

Miller, R. L., Tegen, I., and Perlwitz, J. (2004). Surface radiative forcing by soil dust aerosols and the hydrological cycle. J. Geophys. Res. 109, doi:10.1029/2003JD004085.

Milligan, A., Berman-Frank, I., Gerchman, Y., Dismukes, C., and Falkowski, P. G. Light-dependent oxygen consumption in nitrogen-fixing cyanobacteria plays a key role in nitrogenase protection. J. Phycol. (In Press).

Mills, M. M., Ridame, C., Davie, M., La Roche, J., and Geider, R. J. (2004). Iron and phosphorus co-limit nitrogen fixation in the eastern tropical North Atlantic. Nature 429, 292-294.

Neuer, S., Torres-Padron, M. E., Gelado-Caballero, M. D., Rueda, M. J., Hernandez-Brito, J., Davenport, R., and Wefer, G. (2004). Dust deposition pluses to the eastern subtropical North Atlantic gyre: Does ocean's biogeochemistry respond? Global Biogeochem. Cycle 18, doi:10.1029/ 2004GB002228.

Ohki, K., and Fujita, Y. (1988). Aerobic nitrogenase activity measured as acetylene reduction in the marine non-heteerocystous cyanobacterium Trichodesmium spp. grown under artificial conditions. Mar. Biol. 91, 9-13.

Ohki, K., Zehr, J. P., Falkowski, P. G., and Fujita, Y. (1991). Regulation of nitrogen-fixation by different nitrogen sources in the marine non-heterocystous Cyanobacterium frichodesmium sp. NIBB1067. Arch. Microbiol. 156, 335-337.

Paerl, H. W., and Zehr, J. (2000). Marine nitrogen fixation. In "Microbial Ecology of the Oceans" (Kirchman, D. L., ed.). Wiley-Liss, New York, pp. 387-427.

Paerl, H. W., Prufert-Bebout, L. E., and Guo, C. (1994). Iron-stimulated $\mathrm{N}_{2}$ fixation and growth in natural and cultured populations of the planktonic marine cyanobacteria Trichodesmium spp. Appl. Environ. Microbiol. 60, 1044-1047.

Pan, B., and Vessey, J. K. (2001). Response of the endophytic diazotroph Gluconacetobacter diazotrophicus on solid media to changes in atmospheric partial $\mathrm{O}_{2}$ pressure. Appl. Environ. Microbiol. 67, 4694-4700.

Patterson, C. O. P., and Myers, J. (1973). Photosynthetic production of hydrogen-peroxide by Anacystis nidulans. Plant Physiol. 51, 104-109. 
Pavlov, A. A., and Kasting, J. F. (2002). Mass-independent fractionation of sulfur isotopes in archean sediments: Strong evidence for an anoxic archean atmosphere. Astrobiology 2, 27-41.

Postgate, J. R. (1998). “Nitrogen Fixation.” Cambridge University Press, Cambridge. 3rd ed.

Prosperi, C. H. (1994). A cyanophyte capable of fixing nitrogen under high-levels of oxygen. J. Phycol. 30, 222-224.

Prospero, J. M., and Lamb, P. J. (2003). African droughts and dust transport to the Caribbean: Climate change implications. Science 1024-1027.

Raven, J. A. (1988). The iron and molybdenum use efficiencies of plant growth with different energy, carbon and nitrogen sources. New Phytol. 109, 279-287.

Raymond, J., Siefert, J. L., Staples, C. R., and Blankenship, R. E. (2004). The natural history of nitrogen fixation. Mol. Biol. Evol. 21, 541-554.

Rye, R., and Holland, H. D. (1998). Paleosols and the evolution of atmospheric oxygen: A critical review. Am. J. Sci. 298, 621-672.

Saino, T., and Hattori, A. (1982). Aerobic nitrogen fixation by the marine non-heterocystous cyanobacterium Trichodesmium (Oscillatoria) spp.: Its protective mechanism against oxygen. Mar. Biol. 70, 251-254.

Sarmiento, J. L., Hughes, T. M. C., Stouffer, R. J., and Manabe, S. (1998). Simulated response of the ocean carbon cycle to anthropogenic climate warming. Nature 393, 245-249.

Au7 Sarmiento, J. L., Slater, R., Barber, R., Bopp, L., Doney, S. C., Hirst, A. C., Klieypas, J., Matear, R., Mikolajewicz, U., Monfray, P., Soldatov, V., Spall, S. A., et al. (2004). Response of ocean ecosystems to climate warming. Global. Biogeochem. Cycle 18, (GB3003).

Schmetterer, G. (1994). Cyanobacterial respiration. In "The Molecular Biology of Cyanobacteria" (Bryant, D. A., ed.). Kluwer, Dordrecht, pp. 409-435.

Schopf, J. W. (1993). Microfossils of the early archean apex chert: New evidence of the antiquity of life. Science 260, 640-646.

Shi, T., Bibby, T. S., Jiang, L., Irwin, A. J., and Falkowski, P. G. (2005). Co-evolution of photosynthetic genes in cyanobacteria. Mol. Biol. Evol. 22, 2318-2342.

Siefert, R. L., Johansen, A. M., and Hoffmann, M. R. (1999). Chemical characterization of ambient aerosol collected during the southwest monsoon and intermonsoon seasons over the Arabian Sea: Labile-Fe (II) and other trace metals. J. Geophys. Res. 104, 3511-3526.

Staal, M., Hekkert, S. T. L., Harren, F. J. M., and Stal, L. J. (2003a). Effects of $\mathrm{O}_{2}$ on $\mathrm{N}_{2}$ fixation in heterocystous cyanobacteria from the Baltic Sea. Aquat. Microb. Ecol. 33, 261-270.

Staal, M., Meysman, F. J. R., and Stal, L. J. (2003b). Temperature excludes $\mathrm{N}_{2}$-fixing heterocystous cyanobacteria in the tropical oceans. Nature 425, 504-507.

Summons, R. L., Jahnke, J. H., Hope, J. M., and Logan, G. A. (1999). 2-methylhopanoids as biomarkers for cyanobacterial oxygenic photosynthesis. Nature 400, 554-557.

Sweet, W. J., and Burris, R. H. (1982). Effects of in vivo treatments on the activity of nitrogenase isolated from Rhodospirillum rubrum. Biochim. et Biophys. Acta (BBA)-Bioenergetics 680, 17-21.

Tegen, I., Werner, M., Harrison, S. P., and Kohfeld, K. E. (2004). Relative importance of climate and land use in determining present and future global soil dust emission. Geophys. Res. Lett. 31, doi:10.1029/2003GL019216.

Tuli, R., Naithani, S., and Misra, H. S. (1996). Cyanobacterial photosynthesis and the problem of oxygen in nitrogen-fixation: A molecular genetic view. J. Sci. Ind. Res. 55, 638-657.

Turner, S., Huang, T.-C., and Chaw, S.-M. (2001). Molecular phylogeny of nitrogen-fixing unicellular cyanobacteria. Bot. Bull. Acad. Sinica 42, 181-186.

Underwood, G. M., Song, C. H., Phadnis, M., Carmichael, G. R., and Grassian, V. H. (2001). Heterogeneous reactions of $\mathrm{NO}_{2}$ and $\mathrm{HNO}_{3}$ on oxides and mineral dust: A combined laboratory and modeling study. J. Geophys. Res. 106, 18055-18066.

Urey, H. (1952). "The Planets: Their Origin and Development." Yale University Press, New Haven, CT.

Venrick, E. (1974). The distribution and significance of Richelia intracellularis Schmidt in the north Pacific central gyre. Limnol. Oceanogr. 19, 437-445.

Volk, T., and Hoffert, M. I. (1985). Ocean carbon pumps: Analysis of relative strengths and efficiencies in ocean-driven atmospheric $\mathrm{CO}_{2}$ changes. In "The Carbon Cycle and Atmospheric $\mathrm{CO}_{2}$ : Natural 
Variations Archean to Present"' (Sundquist, E. T., and Broecker, W. S., eds.). American Geophysical Union, Washington, D.C. Geophys. Monogr. Ser. AGU. Vol. 32, pp. 99-110.

Watson, A. J., Lovelock, J. E., and Margulis, L. (1978). Methanogenesis, fires, and the regulation of atmospheric oxygen. Biosystems 10, 293-298.

Wildman, R. A., Hickey, L. J., Dickinson, M. B., Berner, R. A., Robinson, J. M., Dietrich, M., Essenhigh, R. H., and Wildman, C. B. (2004). Burning of forest materials under late paleozoic high atmospheric oxygen levels. Geology 32, 457-460.

Williams, R. J. P., and Frausto Da Silva, J. J. R. (1996). “The Natural Selection Of The Chemical Elements.”. Oxford University Press, New York.

Williams, R. J. P., and Frausto Da Silva, J. J. R. (2002). The involvement of molybdenum in life. Biochem. Biophys. Res. Commun. 292, 293-299.

Woese, C. (1998). The universal ancestor. Proc. Natl. Acad. Sci. USA. 95, 6854-6859.

Wolk, C. P., Ernst, A., and Elhai, J. (1994). Heterocyst metabolism and development. In "The molecular biology of cyanobacteria" (Bryant, E. D. E., ed.). Kluwer, Dordrecht, pp. 769-823.

Wu, J. F., Sunda, W., Boyle, E. A., and Karl, D. M. (2000). Phosphate depletion in the western North Atlantic Ocean. Science 289, 759-762.

Yakunin, A. F., Fedorov, A. S., Laurinavichene, T. V., Glaser, V. M., Egorov, N. S., Tsygankov, A. A., Zinchenko, V. V., and Hallenbeck, P. C. (2001). Regulation of nitrogenase in the photosynthetic bacterium Rhodobacter sphaeroides containing draTG and nifHDK genes from Rhodobacter capsulatus. Can. J. Microbiol. 47, 206-212.

Zehr, J., Wyman, M., Miller, V., Duguay, L., and Capone, D. G. (1993). Modification of the Fe protein of nitrogenase in natural populations of Trichodesmium thiebautii. Appl. Environ. Microbiol. 59, 669-676.

Zehr, J. P., Harris, D., Dominic, B., and Salerno, J. (1997). Structural analysis of the Trichodesmium nitrogenase iron protein: implications for aerobic nitrogen fixation activity. FEMS Microbiol. Lett. 153, 303-309.

Zender, C. S., Newman, D., and Torres, O. (2003). Spatial heterogeneity in aerolian erodibility: Uniform, topographic, geomorphic, and hydrologic hypotheses. J. Geophys. Res. 108, 4543.

Zhang, R., Follows, M., Grotzinger, J. J., and Marshall, J. C. (2001). Could the late permian, deep ocean have been anoxic? Paleoceanography 16, 317-329.

Zhu, X. R., Prospero, J. M., and Millero, F. J. (1997). Diel variability of soluble Fe(II) and soluble total Fe in North African dust in the trade winds at Barbados. J. Geophys. Res. Atmos. 102, 21297-21305.

Zhuang, G., Zhen, Y., Duce, R. A., and Brown, P. R. (1992). Link between iron and sulphur cycles suggested by detection of Fe(II) in remote marine aerosols. Nature 355, 537-539. 


\section{Author Query Form}

Book: Nitrogen in the Marine Environment

Chapter No:35

\begin{tabular}{|c|c|c|}
\hline Query Refs. & Details Required & Author's response \\
\hline AU1 & $\begin{array}{l}\text { Please provide complete details of the } \\
\text { reference "Kustka, } 2003 \text { " in the list. }\end{array}$ & \\
\hline AU2 & $\begin{array}{l}\text { Please note that the Fig. citations } 2.3 \\
\text { to } 2.5 \text { have been renumbered to match } \\
\text { the text description with the fig. legend. } \\
\text { Please confirm whether this is OK? }\end{array}$ & \\
\hline AU3 & $\begin{array}{l}\text { Please provide volume and page num- } \\
\text { ber for the reference "Chandler, F. W. } \\
\text { (1980)." }\end{array}$ & \\
\hline AU4 & Please provide the location of IGBP & \\
\hline AU5 & $\begin{array}{l}\text { Please provide the location of publish- } \\
\text { ers, wherever it is missing. }\end{array}$ & \\
\hline AU6 & $\begin{array}{l}\text { Please update the reference "Milligan, } \\
\text { A., Berman-Frank, I., Gerchman, Y., } \\
\text { Dismukes, C., and Falkowski, P. G.(in } \\
\text { press)." }\end{array}$ & \\
\hline AU7 & $\begin{array}{l}\text { The } 12 \text { author names are retained and } \\
\text { et al. has been added per the } \\
\text { instruction. }\end{array}$ & \\
\hline AU8 & $\begin{array}{l}\text { Please provide complete details of the } \\
\text { reference "Froelich et al., 1979" in the } \\
\text { list. }\end{array}$ & \\
\hline
\end{tabular}

